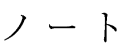

\title{
東京のイネ在来品種「実取らず」の埼玉への伝播
}

\author{
戸倉一泰
}

(埼玉県農林総合研究センター, 熊谷市，テ360-0831）

\section{Dissemination of Native Rice Variety "Mitorazu” from Tokyo to Saitama Prefecture}

\author{
Kazuyasu Tokura
}

(Saitama Prefectural Agriculture and Forestory Reseach Center, Kumagaya 360-0831, Japan)
ら本品種についての資料提供と助言をいただき，2001 年には本品種を栽培，しめ縄生産に従事した農家から聞 き取り調查を行う機会があったことから，資料調查を継 続した結果，本品種が埼玉県で作付されるようになった 経緯と社会的背景，および品種名の由来について概ね明 らかにすることができたので，ここに報告する．

\section{1. しめ縄用品種「実取らず」の品種特性}

収集したしめ縄用品種 2 点について 1989 年と 1990 年 に系統栽培し，特性調査を行った，その結果，双方とも 出穂・程長についてはかなり分離が認められた.しかし, いずれも穎色が黒, 長程, 極晚生で登熟が劣るなどの特 性が一致し, これらの特性は古い品種の特徵とされてい ることから，著者は同一の在来種と判定した．以後の系 統維持と特性調査の労力軽減のため代表個体を選抜, 分 型し純系淘汰を実施した。また試験最終年の1994年に はその他一連の収集品種とともに系統栽培と特性調查を 行った. その結果を表 1 , 表 2 , 写真 1 , 及び写真 2 に示 す. 本品種は上述した特性の他, 金南風より遅く, 埼玉 県では晚生の晚に属し, 脱粒性は難, 程長は $120 \mathrm{~cm}$ 程 度の長秙, 玄米品質は劣り, 葉いもちにも弱いことが判 った。また分げつ期までは葉色はやや淡いが出穂期以降 は葉色が濃く推移することが観察された。

本品種の長稈で稈が太く, 稈質が柔らかく, 葉色が濃 いという特性はまさにしめ縄加工に向くものと考えられ た.

\section{2. 栽培農家からの聞き取り調査}

かって「実取らず」を栽培，しめ縄生産に従事された埼 玉県幸手市の大規模農家U氏に対し聞き取り調査を実 施した。著者が記録した聞き取りの要旨は以下のとおり である。

聞き取り日：2001年 3 月 1 日, 聞き取り場所：U氏自 宅(幸手市)

1)「実取らず」の東京から埼玉への伝播時期と経緯 元々東京で作られていたものが埼玉へ入ってきたもの で，その時期は「昭和 30 年代から作付を始めた. 多いと 
表 1.「実取らず」の生育特性

\begin{tabular}{|c|c|c|c|c|c|c|c|c|c|}
\hline 品種名 & $\begin{array}{c}\text { 収集番号 } \\
\text { およよ゙゙ } \\
\text { 分型系統番号 }\end{array}$ & 出穂期 & $\begin{array}{l}\text { 成熟期 } \\
\text { (月.昌) }\end{array}$ & 倒伏 & $\begin{array}{l}\text { 稈長 } \\
(\mathrm{cm})\end{array}$ & $\begin{array}{l}\text { 穂長 } \\
(\mathrm{cm})\end{array}$ & $\begin{array}{l}\text { 穂数 } \\
\text { (本 / 株 })\end{array}$ & $\begin{array}{c}\text { 葉いもち } \\
\text { 耐病性定) } \\
\text { (特性検定) }\end{array}$ & 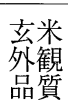 \\
\hline \multirow[t]{4}{*}{ 実取らず } & $88-4$ (4) & 9. 4 & 10.27 & 3.0 & $113.6 \pm 3.5$ & $19.0 \pm 0.8$ & $16.2 \pm 2.4$ & 9 & 6.0 \\
\hline & 88-4(5) & 9. 2 & 10.27 & 4.0 & $116.5 \pm 2.3$ & $20.9 \pm 0.8$ & $14.7 \pm 2.0$ & 8 & 5.5 \\
\hline & $88-5$ (1) & 9. 4 & 10.29 & 4.0 & $123.3 \pm 6.4$ & $20.3 \pm 0.9$ & $15.2 \pm 2.5$ & 8 & 6.5 \\
\hline & $88-5$ (2) & 9. 3 & 10.29 & 4.0 & $127.3 \pm 2.9$ & $19.9 \pm 0.8$ & $15.3 \pm 2.5$ & 8 & 6.5 \\
\hline 金南風 & & 9. 2 & 10.26 & 2.5 & $81.5 \pm 3.1$ & $19.1 \pm 0.8$ & $17.8 \pm 4.7$ & 7 & 6.5 \\
\hline 日本晴 & & 8.24 & 10.16 & 1.5 & $76.5 \pm 2.5$ & $19.8 \pm 1.5$ & $18.4 \pm 3.8$ & 7 & 4.0 \\
\hline
\end{tabular}

1994 年成績, 中苗普通植, 播種日 5.20 移植日 6.15 栽植密度 $30 \times 18 \mathrm{~cm} \quad 18.5$ 株 $/ \mathrm{m}^{2}, 1$ 本植， 1 区制系統配置 1 区 $1.1 \mathrm{~m}^{2} 20$ 株 $\times$ 1 畦, 施肥：基肥 $\mathrm{N} \cdot \mathrm{P}_{2} \mathrm{O}_{5} \cdot \mathrm{K}_{2} \mathrm{O}$ 各 $0.3 \mathrm{~kg} / \mathrm{a}$, 収集時の品種名：88-4(不明), 88-5 江戸川系, 倒伏 : 無 0 微 1 少 2 中 3 多 4 甚 5 の $6 \mathbf{E}$ 階 評価, 程長, 穂長, 穂数は平均值 \pm 標準偏差 (調査 10 個体), 葉いも $5: 0$ 無発病 $~ 9$ 全葉枯死の 10 段階評価, 玄米外観品質 : 1 上上 $\sim 5$ 中中 9下下の 9段階評価.

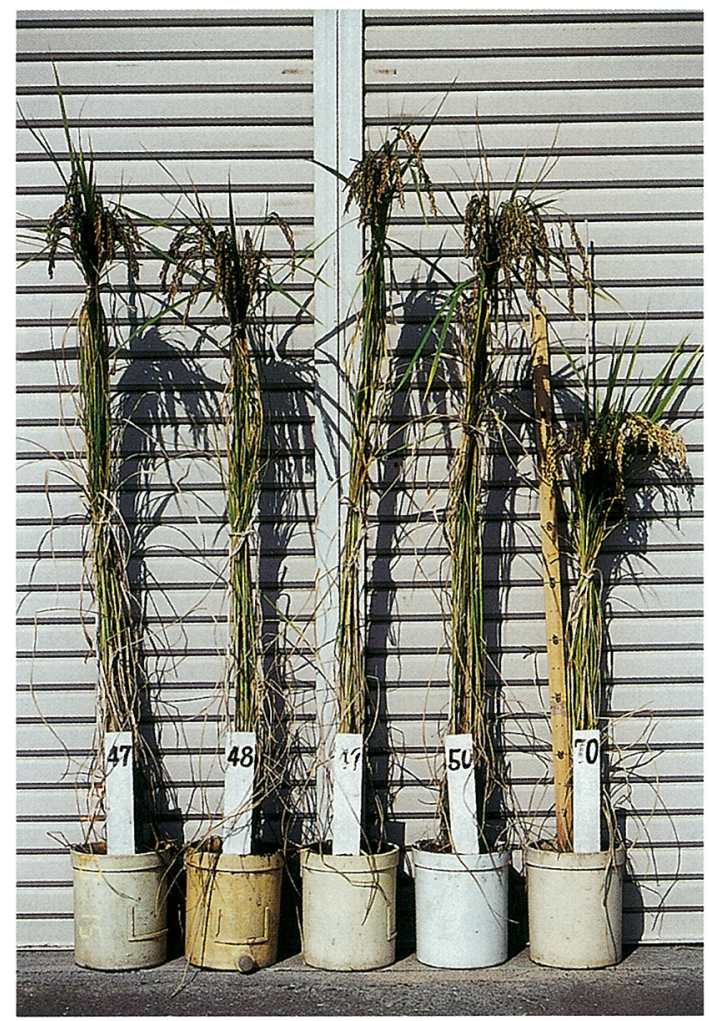

図 1.「実取らず」の草姿

写真左から収集番号 88-4 分型系統(4)代表株，収集番号 88-4分型系統(5)代表株，収集番号 88-5 分型系統(1)代表 株，収集番号 88-5 分型系統(2)代表株，比較「日本晴」

きは年に 20000 本くらい『しめ縄』を作った.」としている ことから 1955 年以降 (昭和 30 年代) と推定できた。東京 の具体的地名としては江戸川区の「鹿骨」があげられた。

\section{2)「実取らず」の栽培方法}

しめ縄用であることから製品の色が重要で収穫前に追 肥を行い葉色を濃くし, 収穫後平型乾燥機で通風乾燥す る. 過去 1 〜 ケ月天日干ししたり，イグサ用乾燥機が 使用されたことがあった。種子は収穫後の再生茎から採 種する.

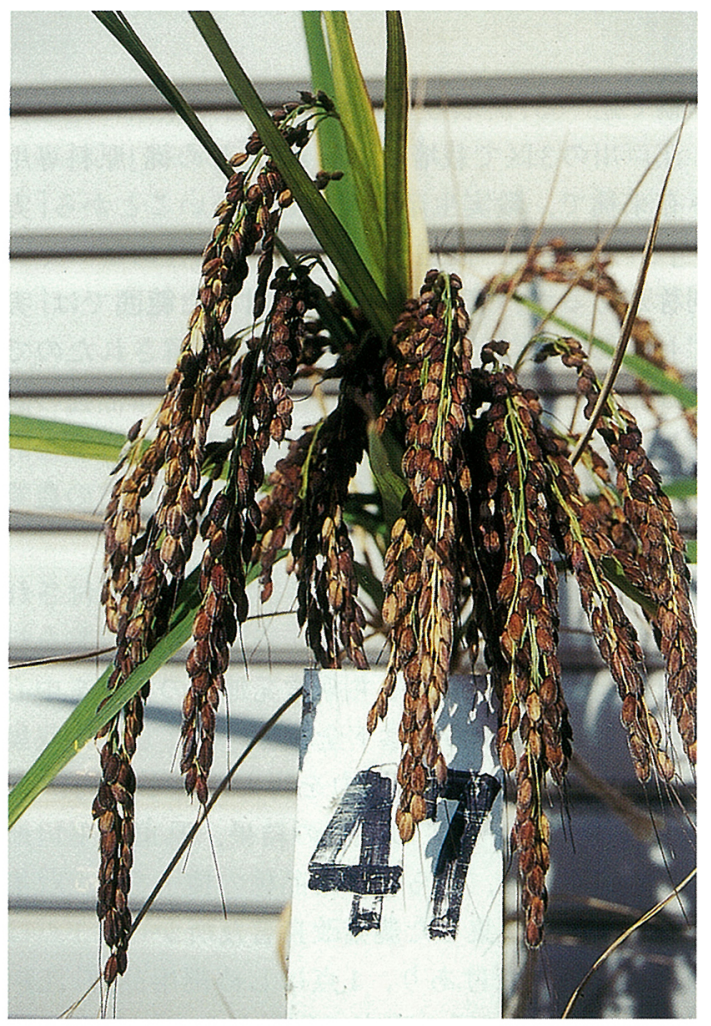

図 2.「実取らず」の穂

収集番号 88-4分型系統(4)代表株

\section{3)「実取らず」で作られたしめ縄の流通}

問屋と職人の関係があり，職人は農家で「実取らず」の 栽培からしめ縄作りまで行う。問屋は年末に浅草寺境内 の北側で開かれるしめ縄の市，「ガサ市」(12月14日〜 12 月 25 日)で小売りに販売する。聞き取りでは「しめ縄 問屋が 20 軒くらい出る」, 「問屋 1 軒が 20 人くらいの職 人を抱えている」と言っていることから職人としての「実 取らず」の栽培農家数は問屋数 $\times$ 職人数で約 400 戸と推 定できた。また「東京の連中がやっていて良い金になり そうなのでうらやましかったがなかなか仲間に入れても らえなかった。やらせてもらっても『場違い』と言って值 
表 2.「実取らず」の一般特性

\begin{tabular}{|c|c|c|c|}
\hline \multicolumn{2}{|c|}{$\begin{array}{l} \\
\text { 項目 }\end{array}$} & 実取らず & 日本晴 \\
\hline \multicolumn{2}{|c|}{ 早晚性 } & 晚生の晚 & 晚生の早 \\
\hline \multicolumn{2}{|c|}{ 草型 } & 偏穂重 & 偏穂数 \\
\hline & 秙長 & ごく長 & 中 \\
\hline \multirow[t]{4}{*}{ 稈 } & 細太 & やや太 & 中 \\
\hline & 剛柔 & やや柔 & 中 \\
\hline & 穂型 & 紡鍾 & 紡鍾 \\
\hline & |粒着密度 & やや密 & やや疎 \\
\hline \multirow[t]{4}{*}{ 穂 } & 穎色 & 黒 & 黄白 \\
\hline & 護穎色 & 紅紫 & 淡黄 \\
\hline & 灾先色 & 紫 & 黄白 \\
\hline & 多少 & やや少 & 極少 \\
\hline \multirow[t]{2}{*}{ 芒 } & 長短 & やや短 & 極短 \\
\hline & 芒色 & 紫 & 黄白 \\
\hline \multicolumn{2}{|c|}{ 脱粒性 } & 難 & 難 \\
\hline \multicolumn{2}{|c|}{ 糯 · 粳の別 } & 粳 & 粳 \\
\hline
\end{tabular}

稲種苗特性分類調查報告書に基づき作成.

段が安く，例えば鹿骨のものと比べ幸手のものは良くて 8 割くらいにしかならなかった」と言っていることから 問屋・職人の関係は固定的, 閉鎖的で新規参入は難しか ったことが判った．さらに「今では向こうから頼まれる ようになったが，忙しくてあまりできない」としている ことから現在では職人が不足しており問屋が職人と製品 の確保に苦労しているものと推察された。なお「品種名 は『みと』，『くろっぽ』とも呼ばれた」としていることか ら「実取らず」には関係者の間で「みと」，「くろっぽ」とい う別な呼称・品種名があることも判った。

\section{3. 東京都内における「しめ飾り製造」と「実取らず」栽培}

上述したように「実取らず」は元々東京で作られていた ものとされていたことから，東京都における「実取らず」 栽培の由来について資料調查を実施した。その結果，東 京都の江戸川，葛飾，足立の 3 区の農家にとっては正月 用「しめ飾り」製造が農業経営上非常に重要であったため 「実取らず栽培」が行われていたこと，正月用「しめ飾り」 独特の製造・流通が行われていたこと，元々「実取らず」 とは栽培法の名称であったことが判った。

\section{1)東京都内における「実取らず」栽培の分布}

東京都の農業図説 (1952)によると江戸川，葛飾，足立 の3区とその他区部を東部湿田地帯として，都下の水田 の $60 \%$ を占めるが，品種，栽培技術への関心は低く， 品種が雑多で奨励品種普及率は低いとしていた。また江 東 3 区の江戸川，葛飾，足立は三多摩に比べ収量水準が 低く，第二次大戦はじめまで正月しめ縄用「実取らず」の 栽培が盛んに行われていたとし，この地域は都市農村と して蔬菜の集約栽培が盛んで, 実をとる稲作の経済的価 值は極めて低いとしていた。また資料調査の結果，足立
区についてはしめ縄用「実取らず」栽培の農業経営上のウ エイトは江戸川区，葛飾区のそれに比べ低く，農家の副 業としては「紙漉」の方が重要であったと判断されたの で，以下の調査は江戸川区，葛飾区に関する資料によっ た.

\section{2)東京都内における「しめ飾り製造」と「害取らず」栽培の 歴史}

江戸川区においては，「正月用のしめ飾り作り」は住民 の信仰や正月行事など生活と密接に結びついた「区内特 産物」で(江戸川区 1976b)，江戸時代から続き，徳川家・ 各大名・旗本 ・商家・芝居小屋などの「しめ飾り」はす心゙ て葛西方面の農家により製造されたとしており，明治以 降も引き続き行われ, 昭和 10 年代から逐次減少し, 戦 後再び復興されたが，以前よりだいぶ減少したとしてい た。「しめ飾り」製造には「実取らず」と呼ばれる稲が使わ れるとしていた(江戸川区 1976a)。昭和7年(1932)の区 制施行以前の状況について南葛飾郡誌(1923)によると, 旧葛西領にあたる南葛飾郡 (現葛飾区・江戸川区)では 「しめ飾製造」の起源は鹿本村 (現鹿骨地区) とその近傍で 明治以前から行われていたとしていた。また正月用しめ 縄飾原料の栽培は本郡農家の副業として有名で「実取ら ず」と称して栽培, 松江村, 瑞江村, 鹿本村, 奥戸村, 南綾瀬村等しめ飾の副業が盛んな町村にあるとし, 品種 は多くの場合, 晚生種で 1 農家あたり 1〜3畧作付され, 稲わらに青味を帯びさせる必要から日陰田に稲を播種 し，土用に刈り取るとしていた。1㽞あたり収量は 170 束であった(南葛飾郡 1923)。また鎌形初太郎日記 (大正 6年 7 月)に扔いては「南綾瀬の注連飾り」として,「沿革 八不明ナレ共モ余程古クヨリ製造シ居タルモノナリ.」と され，しめ飾りの種類として細工物，普通玉，ゴボウ， 大根，定輪(じょうわ)があげられ，このうち細工物は明 治 10 年 (1877) 頃から始めた装飾性の高いもので海老, 日の出，積俵等があるとしていた(鎌形 1978).

以上のように，東京都内における「しめ飾り製造」の起 源は江戸時代とされ，明治 10 年 (1877) 頃には既に地場 産業として成立していたものと考えられる。

次に近年の「実取らず」栽培の状況は，江戸川区では 1976 年時点でしめ縄製造に従事するのは鹿骨〜一之 江・春江方面の 120 戸であり, 原料の「実取らず」生産は 大半近く近県からの買い入れに移行し，以前行われてい た小松川町，松江地区，東一之江方面ではしめ縄製造が 行われなくなったとしていた(江戸川区1976a)，葛飾区 においては 1985 年時点で，水田がなくなったこと，技 術を受け継ぐ人がいなくなったことから区内のしめ飾り 作りはほんの数人になり，原料の「わら」は埼玉県や千葉 県にある自分の水田で生産するか，埼玉県や千葉県の農 家から購入するとしていた(葛飾区 1985).

「実取らず」については，本稿で「実取らず」とした品種 と江戸から明治時代にしめ縄原料とされたものと同一か 
どうか確認はできなかったが，「実取らず」の名称は南暮 飾郡誌(1923)では文脈上から栽培法として, 江戸川区史 第 3 巻 (1976a)では品種名を指すものと読みとれ, 増補 葛飾区史下巻(1985)では栽培法として扱われていたこと から, 元々栽培法の名称であったものが品種名に転叱し 現在では本品種を「実取らず」と称するようになったもの と考えられた。

3)「しめ飾り製造」および「実取らず」栽培の農業経営上の 位置づけ

1983 年に葛飾区が归 7 力町村時代からの住民 17 名 (調 查当時 46 歳から 81 歳)に対し行った面接・聞き取り調 査の結果では「しめ飾り作りの話を抜きにして本区の農 民の生活史を語ることはできない」ほど重要で, その理 由は「昭和 10 年頃 1 シーズン平均で 70 円〜 80 円のもう けがあり，多い家で 100 円， 1 家が 1 年間生活できた」程 のまとまった金額を一度に稼げ「農家の年末の副収入と してなくてはならないもの」であったためであるとして いた。しめ飾りが作られたところの土地柄は，土質が野 菜作りに不向きであり，逆に野菜作りに向いたところは 野菜専業で「しめ飾り作り」ができず, 必要性も薄かった。 そのため水元・新宿地区では「しめ飾り作り」はほとんど なく, 奥戸地区は自家用のみで，しめ飾りの名産地は青 戸・砂原（現西亀有地区）であったとしていた（葛飾区 1985)。旧南葛飾郡では「実取らず」と称する正月用しめ 縄飾原料の栽培は水稲，レンコン，ハナショウブに続く 第 4 の田の作物の地位にあり, 1 シーズン平均 1 人あた り 100 円程度の収入となるため「副業としてかなり重要」 で, 最も盛んな所は南綾瀬村, 亀青村で農家の約 $50 \%$ がしめ飾製作に従事, 大正 10 年調べでは南綾瀬村字堀 切では全戸従事, しめ飾製造の同業組合ができていると していた (南葛飾郡 1923)。また南暮飾郡の北部は乾田 であるが, 中南部ほど深田が多く, 烟の面積は大きくは ないが，「東京市相手の蔬菜農の活動地」として極めて集 約な耕作が行われ, 都市郊外に扔ける蔬菜栽培の有利性 から, 事情の許す限り水田を埋め立て畑地に転換してい るとしていた。亀青村では小作農が水稲耕作をきらって 水田の耕作者を見出せず畑の小作に水田をセットで耕作 させることとし, 畑だけの小作は小作料を倍額に引き上 げたが，それでも小作人は田を捨て畑に就く状況にある としていた(南葛飾郡 1923).

以上のように本地域では野菜栽培に比べ水稲栽培の位 置づけは低かったため, 畑地転換できない地区において 穀実生産より収益性の高い「実取らず」が作付けされてき たものと考えられた。

\section{4)しめ縄の流通と同業者組合}

増補葛飾区誌下巻 (1985)によると, しめ飾りの流通は, しめ飾りの市へ生産者が持参し, 市で生産者が仲介に売 $\eta$, 仲介が客に売る, 主な客は東京のトビ職, 八百屋で
自分の村，町で一般客に売った。しめ飾りの流通には暗 黙の統制があり，組合員でないと注文がこない，作って も仲介が買ってくれないというシステムになっていて， 組合員は市以外では自分の居住地で売ってもいけないと された。しめ飾りの市は 12 月 15 日の浅草観音裏から始 まり神田明神社, 次に芝愛宕神社, 最後に両国の回向院 (大みそか)で終わるとしていた。南葛飾郡誌 (1923)によ ると, 大正 10 年調べでは「注連飾製造に関する同業組合」 ができているとし「これら注連飾は大部分東京の歳の市 に売り出され, 浅草観音市, 神田明神市, 芝愛宕市, 両 国市にもたらされる」としていた。

次に大正 6 年 7 月の鎌形初太郎日記「南綾瀬の注連飾 り」によると,「販路ガ面白ク直接ニ市場タ設ケ販売スル モノニシテ, 直接利益タ見ルガ故ナリ」, 即ち, 自分た ちで市を開き直に金になるとしていた(鎌形 1978).

また，南葛飾郡農会史資料第 5 巻(鎌形1978)には「メ 飾親交会規約」も収録されていた。これは「南暮飾郡及び 南足立郡子飾生産者及び仲買者」「大正 8 年組合組織大正 10 年規約改正」とあるから南暮飾郡誌の「注連飾製造の 同業組合」を指すものと考えられる。本規約は全 17 ケ条 からなり，「ね飾製造業者及びか飾仲買業者」を会員(組 合員）とすること，出店時の会員章所持義務，「製造人」 の市場以外への出荷禁止, 組合員以外の市場での取引禁 止, 各市場での組合員章の検査ほか細部に至るまで取り 決めていた。

以上のことから「しめ縄」の流通は同業者組合成立以前 は自由であったが，大正 8 年 (1919) 以降は同業者間での 明確な統制があり，これが時代の経過とともに慣例化し て 1985 年頃に扔いても続いていたことが判った.

\section{4.「実取らず」の伝承と伝播の特徵}

1)「実取らず」の伝承理由

本品種が成立し, 今日まで伝承されてきた理由は第 1 に江戸川・葛飾の両地域が地理・地勢的条件から副業と してのしめ縄製造が農家の生活上必須で地場産業として 古くから成立したこと，このため「しめ縄製造に向く特 性」という穀実生産とは異なった視点からの品種選択が 行われたこと，第2に同業者組合が成立したことにより， 閉鎖的な社会関係の中で連綿と伝承されてきたものと考 えられた，鎌形勲(1971)は，旧南葛飾郡の農業は日本の 他のいかなる土地よりも都市の影響を強烈に受け, 都市 人口の膨張がそ菜の市場価格の騰貴をもたらした結果， 生産費との関連における米とそ菜の市場価格が東京市部 の稲作の消長に最も強く関与したと述べている. 前述し たように，旧南葛飾郡においては畑だけの小作は小作料 を倍額に引き上げても小作人は田を捨て畑に就くほど野 菜が農業経営上有利であり水稲作の地位は低かった(南 葛飾郡 1923).このため深田で野菜栽培の不可能な地域 においてはレンコン栽培や「実取らず」によるしめ縄製造 が成立・定着し農家の家計を補った，あるいはこれら抜 
きでは農家の生計が成り立たなかったものと考えられ た.

\section{2)「実取らず」の埼玉県への伝播}

馬場 (2000) は東京都の水稲について, 1955 年の 8000 ha をピークにこれ以降, 減少の一途を迻ったとしてお り，特に 1960 年 1975 年の 15 年間は 7000 ha から 1000 $\mathrm{ha}$ へ激減したとしている。また昭和 30 年代の東京都の 水稲は江東 3 区で $50 \%$ を占めたが, 現在これらの農家 の一部は臨県の埼玉, 千葉に出耕作するものが見られる としている，著者は「昭和 30 年代後半」(1960年頃)から 始まった江戸川，葛飾区の農家が埼玉へ出耕作するにあ たり，農家の中に「実取らず」を栽培するしめ縄生産者が あったものと推定している。これが埼玉の農家と「害取 らず」の出会いであったのではなかろうか. 埼玉県幸手 市の栽培農家U氏が「実取らず」の作付開始は「昭和 30 年 代」としている点や，「東京の連中がやっていて良い金に なりそうなのでうらやましかった」例えば鹿骨のものと 比べ, 幸手のものは良くて8割くらいにしかならなかっ た」という聞き取り調査結果, 資料調査において葛飾, 江戸川両区とも 1970 年代から 1980 年代には都市化によ り水田がなくなったことや，後継者不足により「実取ら ず」栽培としめ縄作りは衰退し, 近県への出耕作や原料 の買い入れに移行した(江戸川区1976a，葛飾区 1985) と いう記述と符丁している。

U氏からの聞き取りでは「しめ縄販売業者」は「問屋」, 「しめ縄生産農家」は「職人」としているが，これは「ぬ飾 親交会規約」(鎌形 1978)の「仲買者」,「注連縄生産者」に あたる. 聞き取りでの「問屋」,「職人」は機能分担であり， 「か飾親交会規約」では常設店舗を持たないという意味か らこの「問屋」を「仲買者」としたのであろう．しめ縄の流 通については, 大正時代からの同業者組合の伝統が現在 でも受け継がれていることはU氏からの聞き取り内容 にも見られるが, 上述した江戸川, 葛飾両区の農地・農 家の減少によりやむなく埼玉の農家に生産・製造を発注 するようになったものと考えられた。

以上のように「実取らず」の埼玉県への伝播は，これま で知られている他の在来イネ品種の作付地域拡大とは異 なり, 元の栽培地域の都市化, 農地・農家の減少という 経済情勢や社会変化による周辺地域への拡散であった。 なお「実取らず」の現状における分布については，吉田ら （1993）は本品種の種子を茨城県農業試験場から分譲を受 けており, 埼玉県東部から茨城県霞ヶ浦周辺にかけて分 布しているとしている(吉田私信)。また著者は1997年 に埼玉県北部の熊谷市で，2001年にやはり埼玉県北部 の行田市で自家用と思われる「実取らず」の作付けを認め ており, 本品種は農家間の種子流通により分布を広げて いるものと思われる.
3)「実取らず」の栽培史が示すもの

これまで述べたように食糧増産が国是とされた時代に あっても「実取らず」は根強く作付されてきた，東京の葛 飾区，江戸川区という限定された地域ではあるが，この 事実は「イネを作付ける」という行為の目的が農家の経済 と生計にあることを示していて, 条件次第では穀実を生 産しない稲作すら成立し得る事実を示している。このこ とを裏返せば農家の生計を基軸とし,地域の地理・地勢, 経済的条件を踏まえたものでない限りどのような品種や 技術も定着し得ないということを著者は改めて認識し た.

本品種の栽培は東京の都市の発展とともに明治から大 正時代にかけ隆盛を迎えたが，やがて都市化により周辺 地域へ拡散し, 元の栽培地から消滅するという歴史を辿 った。この「実取らず」の栽培史は，「都市と農村は調和 し得るか」という大きな課題に一つの答えを出してしま っていた。しかしながら著者は一方で出耕作による営農 継続を選択した農家があったことに注目している。なぜ 彼らは出耕作までして営農の継続を選択したのか，この 検討はもはや育種学研究の範疇を離れるが, 著者はここ に都市と農業の新たな関係構築に向けたヒントが見いだ せないかと考えている.

\section{謝 辞}

「実取らず」の収集にご協力いただいた元春日部農業改 良普及所野中修一氏, 元久喜農業改良普及所古澤孝行氏, 聞き取り調查にご協力いただいた幸手市農家U氏なら びに資料調查にご助言いただいた東京都農業試験場馬場 隆氏に深くお礼申し上げます。

\section{引用文献}

馬場 隆 (2000) 日本作物学会関東支部会報 15: 6-7.

江戸川区 (1976a) “江戸川区史第3巻”江戸川区, 東京. 67-70.

江戸川区 (1976b) “江戸川区史第3巻”江戸川区, 東京. 360-361.

䤲形初太郎 (1978) “南葛飾郡農会史資料第 5 巻”鎌形勲浄書複写

製本，東京. 1094-1097.

鎌形 勲 (1971) “南葛飾郡農会史資料第 1 卷”鎌形初太郎編 (1977)，鎌形勲浄書複写製本，東京. 序文1-6.

農林水産情報協会 (1980) 稲種苗特性分類調查報告書：1-112.

東京府南葛飾郡 (1923) “南暮飾郡誌”日本郡誌集成 (1973), 明治 文献, 東京. 336-380.

東京都葛飾区 (1985) “増補葛飾区史下巻”ぎょうせい, 東京. 482-485.

東京都農業試験場 (1952) “東京都の農業図説” 東京都農業試験 場, 東京. 58 .

吉田宣夫 ·武政安一 ·高橋哲二 ·増山忠良 (1993) 日草誌 39(3): 359-363. 